\title{
Working Paperseries
}

\section{Why Central Banks Should Not Burst Bubbles}

\section{Adam S. Posen}

\begin{abstract}
Central banks should not be in the business of trying to prick asset price bubbles. Bubbles generally arise out of some combination of irrational exuberance, technological jumps, and financial deregulation (with more of the second in equity price bubbles and more of the third in real estate booms). Accordingly, the connection between monetary conditions and the rise of bubbles is rather tenuous, and anything short of inducing a recession by tightening credit conditions prohibitively is unlikely to stem their rise. Even if a central bank were willing to take that one-in-three or less shot at cutting off a bubble, the cost-benefit analysis hardly justifies such preemptive action. The macroeconomic harm from a bubble bursting is generally a function of the financial system's structure and stability-in modern economies with satisfactory bank supervision, the transmission of a negative shock from an asset price bust is relatively limited, as was seen in the United States in 2002. However, where financial fragility does exist, as in Japan in the 1990s, the costs of inducing a recession go up significantly, so the relative disadvantages of monetary preemption over letting the bubble run its course mount. In the end, there is no monetary substitute for financial stability, and no market substitute for monetary ease during severe credit crunch. These two realities imply that the central bank should not take asset prices directly into account in monetary policymaking but should be anything but laissez-faire in responding to sharp movements in inflation and output, even if asset price swings are their source.
\end{abstract}

JEL codes: E44, G18, E52, E58

Keywords: bubbles, asset prices, monetary policy, central banks

Note: This working paper is forthcoming as commentary in International Finance 9, no. 1. It will appear alongside an essay by Nouriel Roubini, "Why Central Banks Should Burst Bubbles." The author is grateful for discussions of prior related research with Tamim Bayoumi, Charles Bean, Michael Bordo, Gordon de Brouwer, Stephen Cecchetti, Malcolm Edey, Charles Goodhart, Olivier Jeanne, Anil Kashyap, Kenneth Kuttner, Frederic Mishkin, Michael Prell, Anthony Richards, and Edwin Truman. Samantha Davis and Daniel Popov Gould provided research assistance with those efforts. The author remains solely responsible for the opinions and any errors herein.

Adam S. Posen has been a senior fellow at the Institute for International Economics since 1997. He is the author, coauthor, or editor of The Euro at Five: Ready for a Global Role? (Institute for International Economics, 2004), The Future of Monetary Policy (Blackwell, forthcoming), and Inflation Targeting: Lessons from the International Experience (with B. Bernanke et al., Princeton, 1999), among others.

Copyright (C) 2006 by the Institute for International Economics. All rights reserved. No part of this working paper may be reproduced or utilized in any form or by any means, electronic or mechanical, including photocopying, recording, or by information storage or retrieval system, without permission from the Institute. 
It is difficult to tell from the discourse of the early 2000s which cry is louder: the one from carping Cassandras forecasting imminent doom from the housing price bubble in the United States and elsewhere or the one from moralistic monetarists telling the Federal Reserve to tighten policy forthwith and already blaming the central bank's prior ease for when the Cassandras' prophecies eventuate. That these forecasts have been years overdue in coming to pass and that only a mild short recession followed the past bubble in US equities do nothing to dull the volume.

In fact, it is often claimed that the Federal Reserve's aggressive easing in response to the shocks of 2001 contributed to an unsustainable recovery biased toward consumption and borrowing (never mind ongoing productivity growth) and may have caused the current real estate bubble. It is too bad that reality has to get in the way of such a popular story. Well, it is not too bad because if the Federal Reserve decision-makers were to have believed the story and acted accordingly, they could have done a lot more harm than they have to date by their restraint.

Central bankers should not try to prick, burst, preempt, or even just tighten when confronted by an asset price bubble-except when movements in asset prices directly affect inflation and output forecasts, which are a standard part of their mandate (and that direct effect is relatively limited). If anything, events in the US economy in the 1990s and 2000s demonstrate the benefits of central banks largely ignoring the course of relative asset prices and decisively easing monetary policy in the face of postbubble slumps.

The issue is not whether asset price bubbles occur-all but the most dogmatic market fundamentalists would acknowledge that they do. Nor is the issue that central banks are ill equipped to recognize asset price bubbles. Central bankers have to make decisions based on uncertain and difficult assessments of such indirectly observable variables as potential output and equilibrium exchange rates all the time (Blanchard 2000). Given their information resources and incentives to avoid bias, as well as knowledge of their own plans, central bankers probably have nearly as much advantage in identifying asset price bubbles as they have been demonstrated to have in forecasting GDP (by Romer and Romer 2000, among others).

Central bankers should not try to prick asset price bubbles simply because it is not worth it. Attempts to do so using monetary instruments will almost certainly fail, because the connection between monetary conditions and asset markets is far less tight than most commentators assert. Bubbles themselves cause far less harm to the economy upon bursting than is usually assumed-unless the banking system has significant problems or the central bank makes the mistake of tightening policy in the bubbles'aftermath — so they are not worth diverting monetary policy from its normal duties. And easing monetary policy in response to a postbubble recession (or to the preceding negative shock to investment demand) rectifies much of the status quo ante without in fact inducing the moral hazard or follow-on bubbles some hypothesize must occur (e.g., Miller, Weller, and Zhang 2002). Central banks like the Federal Reserve are right to ignore efforts to blow bubbles out of proportion as a monetary policy issue. 


\section{GETTING THE “EXCESS LIQUIDITY CREATES BUBBLES” MYTH OUT OF THE WAY}

As Mervyn King (2003) has observed, it is somewhat ironic that discussions of monetary policy today largely do not consider money itself, either empirically with regard to growth in monetary aggregates or theoretically in the models on which monetary policy decision-making is based. Whether this is merely ironic and reflects the long lags with which economic language changes or is in fact a matter for some concern remains in dispute. Of late, macroeconomists with a monetarist bent have seized upon the interest in having central bankers preempt bubbles as new means to justify targeting (or at least tracking) of growth in monetary aggregates.

Otmar Issing (2003), for example, argues that the monetary pillar of the European Central Bank's strategy can be seen as useful in the prevention of excessive liquidity that leads to equity or real estate booms - even though at the time of launching the ECB's two-pillar strategy, such use was never mentioned. Even such Anglo-Saxon liberal paragons as Martin Wolf writing in the Financial Times, or the leader writers of the Economist, have joined the chorus that "excess liquidity" must be the cause of asset price booms and that such monetary excess will inevitably lead to economic purgatory. This is a toothpaste tube view of liquidity_once the paste has been acquired, if the tube is squeezed at one point, it will just bulge out at another.

Such thinking is demonstrably incorrect as a description of reality. Much of the work in monetary economics in the 1980s was on establishing that monetary aggregates neither have predictable relationships with economic variables of concern nor have dependable utility as an instrument of monetary policy, and later studies have confirmed those results. ${ }^{1}$ Inspired by the views of Issing (2003), Crockett (2002), and others, however, recent econometric investigations have attempted to establish a direct link between measures of central bank liquidity and growth in asset prices, either of real estate or equities. These efforts have failed to find any robust or direct connection. ${ }^{2}$ Borio and Lowe (2002) come closest by finding that bubbles have some statistical correlation with "long credit booms," a statement that gives as much guidance to central bankers as the fact that excessive wage growth is associated with prolonged recoveries, neither necessary nor sufficient for such wage inflation. Even the simple statement that tight monetary conditions would prevent the rise of bubbles has proved surprisingly difficult to confirm.

1. The leading figures in this literature are Benjamin Friedman, Charles Goodhart, and Frederic Mishkin. Later studies confirming that even the self-declared monetary targeters such as the Bundesbank and Swiss National Bank did not actually target monetary aggregate growth in any meaningful sense include Bernanke and Mihov (1997), Clarida and Gertler (1996), and Laubach and Posen (1997); Rich (2003) gives a practitioner's view confirming these results. The only rejoinders of note have been studies showing correlations between monetary growth and economic outcomes at extremely long horizons (five years and up), which is of little relevance to monetary policymaking and which raises issues of reverse causality.

2. See Borio and Lowe (2002), Bordo and Jeanne (2002), and Detken and Smets (2004). 
I investigated the relationship between periods of monetary ease and independently identified instances of asset price booms (Posen 2003a). Bordo and Jeanne (2002) identified 18 booms in property prices and 24 share price booms followed by busts in 15 OECD economies between 1970 and 2000 (1998 for property). ${ }^{3}$ Separately, I established a list of periods of monetary ease for the same countries and sample years (Posen 2003a); a period is classified as displaying monetary ease if either the central bank's instrument (overnight) real interest rate is less than 1 percent or M3 (broad credit aggregate) growth exceeds the average growth rate by one-standard deviation for a sustained period. ${ }^{4}$ The contention that "if monetary ease, then comes a bubble" is unsupported-just over a third of instances of monetary ease on either measure resulted in asset price booms (of which 12 were overlapping equity and real estate booms and 5 were solely real estate booms).

Meanwhile, the contention that monetary ease is necessary for an asset price boom to arise (if there's a boom, it must have been preceded by ease) is similarly rejected for share price booms, 12 of which arose when monetary conditions were not easy. There is, however, only one instance of a real estate boom occurring without being preceded by monetary ease, which suggests that ease is usually needed for real estate booms to occur. But still, monetary ease—also known as excess liquidity—is not sufficient alone for a property boom to arise. Thirty-one periods of sustained monetary ease in the last 30 years of the $20^{\text {th }}$ century in the OECD economies did not result in property (or share price) booms, while fewer than half that many did result. The consideration of additional explanatory variables in recent research does nothing to yield a tighter connection; if anything it yields just the opposite. ${ }^{5}$

So, should central bankers forego monetary easing justified by the usual macroeconomic criteria because of a one-in-three chance that such easing might allow a real estate boom (and a one-in-four chance an equities boom) - especially when equity if not real estate bubbles can arise anyway, even under

3. The identification is done mechanically using a statistical criterion for sustained growth of asset price indices above average rates. The list proves to be relatively robust to variation in the statistical cutoff. Detken and Smets (2004) come to a similar list looking solely at equity price booms.

4. These are actually relatively inclusive definitions of monetary ease- - one could justifiably make the cut off for ease an interest rate below zero and/or M3 growth more than 1.5 standard deviations above average. Restricting the sample in this manner does not lead to a tighter association between "ease" and booms (in fact, it leads to more instances of booms taking place during periods of nonease). Similarly, shifting the focus to narrower monetary aggregates as measures of liquidity does nothing to bring out a correlation.

5. Roubini (2006) argues that this interpretation of these correlations (or lack thereof) from Posen (2003a) is "irrelevant" because the "relevant issue is whether, whatever the bubbles are caused by, monetary policy should react to a bubble." This claim misses the point in two ways: First, if there is no consistent statistical relationship between monetary ease and bubbles, that provides reason to doubt that withdrawal of monetary ease would have any effect on bubbles. One cares about the source of bubbles because that determines which policies will be effective and which will not in influencing them (see next section). Second, if monetary ease only causes or at least leads to bubbles when the economy is already expanding, as Roubini claims (without statistical support for that position-Borio and Lowe (2002) and Detken and Smets (2004) would have found that correlation in their econometric exercises if it was there in the data), then normal monetary policy that stabilizes inflation and output should lead to a policy reaction (an end to ease if not tightening) in any event without considering asset prices. In other words, monetary policy already reacts except in those rare cases where asset prices go up but both growth and inflation appear sustainable, which leads one to wonder why the bubble is a problem in the first place. 
less than easy monetary conditions? Only if the probability-weighted costs of allowing such a bubble to arise and then burst would be greater than the loss from the foregone monetary ease. ${ }^{6}$ If a condition other than monetary loosening itself is what makes a bubble likely or costly, like poor bank capitalization and supervision for example, then the appropriate policy response would be to fix that other condition rather than distorting monetary policy. These two issues - the cost of bubbles and the dependence of that cost on nonmonetary factors - are discussed below. For now, one should simply note that with a one-in-three risk juxtaposed with a certain loss from foregoing optimal monetary policy, the bar is set rather high to justify the deviation from normal policy duties to stabilize the economy. Monetarist claims that ease means bubbles are unfounded.

\section{MONETARY POLICY IS TOO BLUNT AN INSTRUMENT TO PRICK BUBBLES WITH ANYWAY}

Before turning to the costs of bubbles, another monetarist assumption behind advocacy of pricking bubbles should be debunked: that monetary tightening actually would succeed in cutting off an asset price boom. If by definition bubbles are not based on economic fundamentals but either on "animal spirits" and confidence or on belief in the greater fool theory, or some combination thereof, then there is no reason a priori to think that a change in liquidity will necessarily stop further price rises. As is well known, Alan Greenspan characterized US share prices as the result of "irrational exuberance" as early as December 1996, and other members of the Board of Governors such as Larry Lindsay were even more outspoken. The markets shrugged it off. ${ }^{7}$ Similarly, the Bank of Japan started expressing doubts publicly about share and real estate price levels as early as 1987, and then even started raising interest rates, but Japan's great bubble went on building until January 1990, ending only when direct credit controls on real estate lending were imposed. ${ }^{8}$

Given the well-established fact that central banks today directly influence only a small portion of capital markets with their open market operations and setting of short-term interest rates, and that the primary means of transmitting monetary policy is through expectations, it is difficult to see why there should be a mechanical connection between tighter monetary conditions and investor behavior. If investors truly believe that there is money to be made in a bubble, and usually are counting on making large amounts of money (which is why it is a bubble in the first place), it seems strange to think that a

6. This may well understate the case against foregoing normal monetary policy decisions to prevent the possibility of a bubble. Bernanke and Gertler (1999) point out the costs of recessions, particularly under conditions of financial fragility; DeLong (2002) reminds us that share price booms are historically associated with the introduction of new technologies, and cutting off the boom early could interfere with the adoption of said technology. In short, the choice need not be symmetric (as is usually assumed by advocates of preempting bubbles), with the net cost of allowing bubbles coming mostly in the form of financial volatility that has limited real effects, but recession having substantial real impact.

7. Shiller (2005) gives an insightful interpretation and history of the period.

8. See the discussion in Posen (2003a), Jinushi, Kiroki, and Miyao (2000), Hoshi and Kashyap (1999, 2001), and Cargill, Hutchison, and Ito (2000). 
marginal rise in interest rates would be sufficient to alter their actions. If the central bank were truly the only source of liquidity in town, cutting investors off when they had too much credit or were deemed to be taking on too much risk might be effective.

But central banks, and the commercial banks they lend to, are not investors' only source of liquidity. Just as drunkards or gambling addicts who have less money will forego basic needs or sell personal items to continue their binges, investors who wish to ride a boom upward will sell or mortgage safer assets to do so, or they will look abroad for credit, as necessary. If investors believe in supra-normal market returns being available to them, a mere rise in short-term interest rates will only tell them they need to invest more.

Ultimately, halting a bubble in a modern economy is less a matter of the central bank trying to choke off liquidity, which it may be unable to do short of draconian monetary tightening that induces a full-bore recession, than of that central bank persuading investors to reevaluate their investments. Such powers of persuasion cannot be counted upon, especially in the face of irrational exuberance. This is also why the issue of central banks' ability to recognize bubbles is moot in the end-whether or not they can identify unsustainable asset price booms with a high degree of accuracy, or at least higher than the average investor, the difficulty is in convincing the investing public that such booms are indeed unsustainable (or that the individual investor will not get out in time).

\section{BUBBLES CAUSE MAJOR HARM ONLY WHEN THE FINANCIAL SYSTEM IS FRAGILE}

The connection between monetary ease and bubbles is tenuous, and the ability of monetary tightening to prick bubbles is even more so. Still, if the harm to the economy from a bubble inflating and then bursting were great, a central bank might be duty bound to take a shot at pricking the bubble nonetheless, regardless of limited prospects for success. Yet, it is difficult even to establish that bubbles bursting is all that harmful, at least in developed economies, even though that harm is often taken for granted. In fact, it turns out that the impact of bubbles on the macroeconomy has far more to do with financial supervision and regulation than with anything monetary policy does.

There is a plausible story for how an asset price boom and bust might do harm to the economy in a manner that should raise policymakers' concern. The first step is that during the boom phase, there is sufficient distortion in relative asset prices that investors run up levels of debt that will prove unsustainable when asset prices inevitably "fall back to earth." This story is often invoked when describing the current US housing price bubble, with the extensive use by American consumers of cashout refinancing from paper gains on owner-occupied real estate. Such excess would depend upon the financial institutions doing the refinancing, either being unconcerned that the default rate on their loan portfolio will (inevitably) rise or simply believing, like the consumers, that real estate prices will not fall, and/or they can find some greater fool to sell securitized mortgages to before the collapse comes.

Whichever way this story is told, it is difficult to see how monetary tightening beyond that in response to the usual assessments of future inflation and growth is the correct policy. For households, 
this borrowing is a problem to the degree that it involves moving consumption forward in time beyond what future income can cover (if the borrowing is invested productively, be it in education or simply in higher-yielding assets that diversify the family's portfolio out of housing, the debt is probably welfare enhancing and raises or stabilizes income over the long run). A sudden shortfall in income will happen only in those households that have adjustable-rate or balloon payment mortgages, so that for a given income level the share of debt payments will rise or in those households that must sell their homes when the amount garnered from the sale is lower than the outstanding principal on their mortgage-primarily those that borrowed at the height of the bubble and sold soon after the peak.

These households are only a fraction of all households in the US economy. These are also not the poorest people in the United States, because the poor remain credit constrained and thus along with the young make up the majority of the $30+$ percent of American households that rent rather than own their residences. In fact, these are mostly households with steady employment (except potentially those recently hired in the construction sector, which would of course respond first to a real estate bust) since they got the loans and were planning on living in the house used as collateral for borrowing. And for that reason, the share of this fraction that will be unable to either sell sufficient assets or cut consumption (including of housing services by moving to smaller or less expensive residences) such that they can rebalance outlay and income is small.

This is not to trivialize the pain of adjustment for some households but to question why this somehow becomes a matter of central bank concern. Sometimes a specific region within a monetary union falls behind others, or particular industrial sectors undergo secular decline, and the people who happen to be employed in that region or sector are forced to adjust without any talk of preempting such events by national monetary policy; why is it any different for a particular sub-class of borrowers? In any event, if household indebtedness indicates that aggregate consumption would dip a little more than usual in the next downturn, that would seem to militate toward less aggressive or shorter-duration interest rate hikes, rather than more. There is no reason to think this direct consumption shock has lasting or large multiplier effects for the economy as a whole. There certainly is no reason to assume such a terribly negative result beyond the usual give and take of economic adjustment over the business cycle that it justifies preemptively depriving the rest of the economy's households of an expansion that has not resulted in forecasts of excessive inflation or reached a natural end. ${ }^{9}$

It is only when one considers the potential effects on the financial system that the central bank is forced to take notice. Obviously, no serious macroeconomist who allows balance sheets, let alone credit markets and nominal rigidities, to play a meaningful role in her macroeconomic models would deny that significant declines in asset prices can have real effects. The economic effects of asset-price busts are likely to be particularly acute when nominal debt and collateral interact with the provision of credit

9. See Bernanke and Gertler (1999) for a related argument against pre-emption emphasizing the corporate sector and equity price boom/busts, where arguably the asymmetry is more pronounced, and thus an easier case to make for central bank foregoing preemption. 
through a banking system (Bernanke 1983, Kiyotaki and Moore 1997). Overhangs of distressed real estate and a credit crunch for small businesses dependent upon bank lending are certainly characteristics of the worst recessions in modern economies. With financial intermediaries as a transmission mechanism, one can imagine circumstances under which an asset price bust could lead through destruction of those intermediaries' information capital to a protracted recession (as arguably was the case in the US Great Depression).

The size of such negative effects in practice, however, importantly depends upon structure and condition of the financial system at the time of the asset price shock. Mishkin and White (2002), for example, consider 15 US stock market crashes over the preceding 100 years and find that only 8 generated "some" or "severe" financial distress, and in turn not all of those led to sharp economic contractions. I show that Japan's broader price deflation following the 1990 bubble burst was the exception rather than the rule-while price deflation is not uncommon in the OECD economies, the vast majority of the deflation episodes were not preceded by asset price busts within 36 months of starting, and the vast majority of asset price busts did not lead to deflation (Posen 2003a). ${ }^{10}$

Well-capitalized and properly supervised banking systems tend to multiply shocks less. Financial systems where there is a greater availability of alternative forms of credit to collateralized bank lending, and where bank loans are securitized rather than kept on banks' books, also tend to be more resilient to asset price shocks. ${ }^{11}$ The sharply different performance and adjustment of the US economy following the late 2001 technology bubble's bursting from that of the Japanese economy following that bubble's bursting 11 years earlier is the ultimate illustration of this point. In contrast, the Great Depression in the United States, like Japan's Great Recession, did not arise immediately or even quickly following the asset price bust - in both cases, it was only when severe banking system distress was combined with damagingly tight monetary policy over a period of years that a truly deep and persistent decline in nominal output arose. ${ }^{12}$

Thus, bubbles' damage to the economy is really not a monetary issue but an issue of financial structure and supervision. So if the financial system, particularly the banking sector, is properly capitalized and overseen, the chances are small of an asset price bust becoming a macroeconomic problem worthy of preempting on its own terms (rather than just a normal negative shock to which good monetary policy would respond with ease as part of its regular forecasting). Combine that with

10. In a 15 OECD country sample, of 9 instances of consumer price deflation of two quarters or more between 1970 and 2000, only 2 were preceded by equity price busts and none by property price busts; of 73 instances of wholesale price deflation, 17 ( 22 percent) were preceded by equity price busts and 9 by property price busts. Meanwhile, only 2 of 24 share price busts and none of 18 property price busts led to consumer price deflation within 36 months of asset price peaks. See Posen (2003a) for details.

11. See the literature on the different performance of various East Asian economies following the financial crisis of 1997-98 (e.g., Greenspan 1999, Council on Foreign Relations 1999), as well as on the faster recovery of the US economy following its share price bust in 2001 compared with that of Japan 10 years earlier (e.g., Posen 2003a, Harrigan and Kuttner 2003).

12. See Bernanke $(1983,2000 \mathrm{~b})$ on the United States in the 1930s and Posen $(1998,2003 \mathrm{~b})$ on Japan in the 1990s. 
the previously mentioned limited ability of monetary policy to actually prick the irrational expectations underlying bubbles, and the only weak at best connection between monetary ease and the occurrence of bubbles, and there is little compelling reason for central banks to react to asset price movements.

\section{WHAT IF THE FINANCIAL AUTHORITIES DID NOT DO THEIR JOBS?}

Of course, central bankers cannot count on banking supervisors or budgetary officials to stick to the straight and narrow, even if one assumes that a politically independent central bank will pursue largely the right policy. Japan in the 1990s is a particularly salient illustration of the dangers of lack of coordination between financial and monetary authorities. Arguably, there was a three-way game of chicken between the Bank of Japan, the Ministry of Finance, and the new Financial Services Agency that paralyzed policy for the second half of the 1990s: The BoJ argued that it could not ease monetary policy aggressively absent banking system reform (to make policy transmission possible) and diminished fiscal demands for bond purchases; the FSA claimed it could not clean up the banking system problems absent monetary ease and partial public recapitalization; and the MOF insisted that it needed financial reform and price stability before it could tackle any issue. ${ }^{13}$ Now that it is increasingly common for central banks to shed or lose direct supervisory responsibility for much of the banking system, and that financial deregulation makes it more difficult to see where banking problems might start and end, the potential for such conflicts will likely increase. ${ }^{14}$

The implication for monetary policy of any financial-system fragility that results, however, is not necessarily the one commonly asserted among the bubble conscious. Should a central bank confronted by a weakened financial system be more aggressive about tightening credit conditions? Is the case for such tightening strengthened by the coincidence of a contemporaneous asset price inflation and prospect of bust? No and no. If the chorus of calls on the BoJ from the IMF, OECD, other G-7 governments, and the overwhelming majority of monetary economists to aggressively counter deflation (that is, loosen policy) — in the second half of the 1990s — in the face of well-documented and repeatedly discussed banking system distress - is any indication, then the considered opinion of the universe of monetary policymakers is that ease is the appropriate response. Consider the widely praised efforts of the Federal Reserve to maintain a steep yield curve at the start of the 1990s when the US banking system was recovering from a property market bust and the significant fragility wrought by the collapse of the savings and loan industry. Consider as well the salutary results of the BoJ reversing policy to more aggressively fight deflation since Toshihiko Fukui became governor in April 2003, independent of the fact that banking system reform under the leadership of Heizo Takenaka had only begun in earnest.

13. Meyer (2000) and Posen (2001) are two examples of interpretations in this vein. Bernanke (2000a) gives a broader critique of Japanese monetary policy "paralysis" during this period.

14. See the discussions in Schinasi (2005a, 2005b) of the need to rethink financial crisis response infrastructures. 
Going beyond the relevant examples to examine the underlying logic, the case for avoiding premature tightening is all the more clear. The now-widely accepted credit channel view of macroeconomics, with its basis in the imperfect information approach to financial markets, stresses the importance of bank capital and of the difficulty to transfer or verify information to investment decisions. ${ }^{15}$ In short, when times are tough, the equity of both banks and borrowers erodes, and the incentives increase for both of them to forego productive investment activities in favor of maintaining loan payments or gambling on resurrection. A rise in interest rates or other tightening of monetary policy that resulted in less availability of credit would only increase the adverse selection problem (the difficulty of sorting out which borrowers would be worthy of credit), the number of borrowers short of equity and thus with perverse incentives, and overall financial fragility. Given information problems, there is no reason to think that an increase in interest rates would "punish" the more spendthrift banks and borrowers for their supposed lack of discipline during the bubble's expansion. A widespread decrease in the value of collateral following a bubble's burst, say in real estate that led to illiquid property markets, would itself only exacerbate the harms that an interest rate rise would inflict upon the economy.

Central banks are not all powerful, and their monetary toolkit has only limited applicability. A problem elsewhere in the economy - even in the financial sector, which is closely connected to monetary policy - cannot necessarily be resolved with monetary policy itself. In fact, to the degree that the central bank has an interest in financial stability - both as part of its fundamental mandate and as a means of securing the transmission of monetary policy-it probably has an interest in easing in response to asset price busts. A government transportation agency that finds out that the housing inspectors misguidedly let unsound skyscrapers be built on landfill or a seismic fault would not be right in going ahead with plans to dig underground highway tunnels next to those buildings until those buildings were shorn up. The transportation agency might itself make particular efforts to shore up those buildings while pursuing its highway expansion, even though it is not its responsibility. Similarly, the central bank cannot simply ignore or punish financial fragility, whatever its monetary policy intent, and whatever other agency fell down on the supervisory job.

The oft-mooted claim that there was a "Greenspan put" in stock markets (formally modeled in Miller, Weller, and Zhang 2002) has found no empirical support-many of those who participated in the US equity price boom of the 1990s lost sufficient money (or engaged in sufficient fraud) to be unable to participate in further speculation on real estate or equities in the 2000s. Other small investors simply were burnt sufficiently badly, having had their first personal experience with the boom-bust cycle, that they are reluctant to invest again in speculative assets. In a broader panel of bubbles, I find weak evidence of negative-not positive-serial correlation in bubbles, i.e., that allowing a bubble to inflate and burst tends if anything to decrease the likelihood of another bubble occurring in short order (Posen 2003a). Subdividing the sample by those instances where central banks eased after asset price busts does nothing

15. Bernanke, Gertler, and Gilchrist (2000) gives a summary of this literature. 
to turn the correlation positive. So a central bank that manages somehow to be perceived as having pricked a bubble, or at least unwilling to be accommodative in their aftermath, does nothing to deter future bubbles, while probably doing the economy further harm.

\section{ASYMMETRIC MONETARY RESPONSE IS THE RIGHT RESPONSE}

In summary, central banks should not be in the business of trying to burst asset price bubbles. Bubbles generally arise out of some combination of irrational exuberance, jumps forward in technology, and financial deregulation (with more of the second in equity price bubbles and more of the third in real estate booms). Accordingly, the connection between monetary conditions and the rise of bubbles is rather tenuous, and by raising interest rates a central bank is unlikely to achieve what is needed-i.e., persuading investors that the bubble is ill-founded and/or that they will not find some greater fool to sell to in time. More important, the cost of bubbles bursting largely depends upon the structure and fragility of the economy's financial system. A properly supervised and regulated financial system—or one with more securitized and liquid markets than bank-dependent-will not suffer much in real terms from a bubble expanding and bursting. If the financial system is fragile or improperly supervised, then monetary tightening will be even more costly in real economic terms, but such tightening in no way substitutes for directly dealing with the underlying financial problems.

The lack of monetary tightening's effectiveness to pop bubbles or to respond to financial fragility and the far greater cost of inducing recessions than riding bubbles out are structural factors characteristic of modern financial systems and bubbles. The cost-benefit analysis inherently goes against popping bubbles and in favor of monetary easing after busts because there is an asymmetry in the way investors and financial intermediaries behave in the two situations. In the end, no amount of monetary discipline can substitute for lack of proper financial regulation and supervision. In fact, there is a clear case why the two are negatively related because tight credit conditions exacerbate imperfect information problems, favoring during asset price busts those borrowers and banks that were most undisciplined during the boom years. ${ }^{16}$ It is not "going easy" on the financial sector to recognize these realities; if anything, recognizing that monetary policy tightening cannot fix a financial-sector problem is an argument for how essential discipline-enhancing financial regulation and supervision are. Foreswearing monetary ease in the aftermath of bubbles to forestall moral hazard (and follow-on bubbles) chases a chimera for which there is little empirical evidence, while imposing a certain cost: failing to expand monetary policy when prices

16. Posen (1998) summarizes the literature on the relationship between imperfect information, credit markets, and business cycles, which concludes that, in a cyclical downturn or time of tightened credit conditions (or both), adverse selection is likely to worsen rather than improve, and monetary discipline will likely lead to credit being rolled over to precisely those sectors which were inefficiently lent too much during the boom years (because writing off their large outstanding loans would do the most harm to banks' impaired capital). Econometric analysis clearly shows that this is precisely what occurred in Japan when monetary policy tightened in the early and mid-1990s following that economy's asset price busts. See Hoshi and Kashyap (1999, 2001), Mikitani and Posen (2000), and Posen (2003a), and the references therein. 
and output are forecast to be falling and stabilization would normally be expected. This asymmetric response therefore does not rely on arguments about uncertainties for central banks in recognizing bubbles but on certainties about the structure of the economy.

Many of those calling for central banks to burst bubbles preemptively, and to foreswear easing policy after bubbles burst, see such asymmetries as aesthetically, perhaps even ethically, disturbing (e.g., Roubini 2006). Yet the economy and the resulting optimal policy prescriptions are not necessarily symmetric. We know, for example, that monetary policy is less effective "pushing on a string" to stimulate low demand when instrument interest rates near zero, while it remains potent in its effect on the real economy by raising interest rates from the same level. We also know that recessions and expansions in the US and other countries' business cycles are far from symmetrical in duration or depth-in the United States, recoveries have been far longer than recessions for much of the past 25 years, for example. Similarly, central banks should loosen monetary policy in reaction to an asset price bust but not tighten in response to an asset price boom, all else being equal, because that corresponds to the uneven way in which financial systems transmit shocks. This argument is independent of more general laissez-faire versus activist arguments about the role of monetary policy—it concludes that central banks should not be active in addressing asset price movements per se but should be anything but laissez-faire in responding to forecasts of sharp movements in inflation and output, even if asset price swings are their source. 


\section{REFERENCES}

Bernanke, Ben. 1983. Non-Monetary Effects of the Financial Crisis in the Propagation of the Great Depression. American Economic Review 73: 257-71.

Bernanke, Ben. 2000a. Japanese Monetary Policy: A Case of Self-Induced Paralysis? In Japan's Financial Crisis and Its Parallels to U.S. Experience, ed. Ryoichi Mikitani and Adam Posen. Washington: Institute for International Economics.

Bernanke, Ben. 2000b. Essays on the Great Depression. Princeton, NJ: Princeton University Press.

Bernanke, Ben, and Mark Gertler. 1999. Monetary Policy and Asset Price Volatility. In New Challenges for Monetary Policy: A Symposium Sponsored by the Federal Reserve Bank of Kansas City: 77-128. Federal Reserve Bank of Kansas City.

Bernanke, Ben, Mark Gertler, and Simon Gilchrist. 2000. The Financial Accelerator in a Quantitative Business Cycle Framework. In Handbook of Macroeconomics, ed. John Taylor and Michael Woodford. Amsterdam: North Holland.

Bernanke, Ben, and Ilian Mihov. 1997. What Does the Bundesbank Target? European Economic Review (June) 41, no. 6: 1025-54.

Blanchard, Olivier. 2000. Bubbles, Liquidity Traps, and Monetary Policy. In Japan's Financial Crisis and Its Parallels to U.S. Experience, ed. Ryoichi Mikitani and Adam Posen. Washington: Institute for International Economics.

Bordo, Michael, and Olivier Jeanne. 2002. Monetary Policy and Asset Prices: Does "Benign Neglect" Make Sense? International Finance 5, no. 2: 139-64.

Borio, Claudio, and Philip Lowe. 2002. Asset Prices, Financial, and Monetary Stability: Exploring the Nexus. BIS Working Papers 114. Basel: Bank for International Settlements.

Cargill, Thomas, Michael Hutchison, and Takatoshi Ito. 2000. Financial Policy and Central Banking in Japan. Cambridge, MA: MIT Press.

Clarida, Richard, and Mark Gertler. 1996. How the Bundesbank Conducts Monetary Policy. NBER Working Papers 5581. Cambridge, MA: National Bureau of Economic Research.

Council on Foreign Relations. 1999. Safeguarding Prosperity in a Global Financial System: The Future Financial Architecture Report of an Independent Task Force. Washington: Institute for International Economics.

Crockett, Andrew. 2003. Central Banking under Test? In Monetary Stability, Financial Stability, and the Business Cycle: Five Views. BIS Papers 18. Basel: Bank for International Settlements. 
DeLong, J. Bradford. 2002. Macroeconomic Vulnerabilities in the Twenty-First Century Economy: A Preliminary Taxonomy. Paper presented at a conference on Stabilizing the Economy: Why and How? New York: Council on Foreign Relations (July). (Forthcoming in Stabilizing the Economy: Why and How? ed. Adam Posen and Benn Steil, Blackwell.)

Detken, Carsten, and Frank Smets. 2004. Asset Price Booms and Monetary Policy. ECB Working Paper 364. Frankfurt: European Central Bank.

Greenspan, Alan. 1999. Do Efficient Financial Markets Mitigate Financial Crises?

Paper presented at the Financial Markets Conference of the Federal Reserve Bank of Atlanta, Sea Island, Georgia, October 19.

Harrigan, James, and Kenneth Kuttner. 2003. Is the U.S. Going the Way of Japan? Solutions for the Japanese Economy Project, Columbia University, Federal Reserve Bank of New York, July. Photocopy.

Hoshi, Takeo, and Anil Kashyap. 1999. The Japanese Banking Crisis: Where Did It Come From and How Will It End. In NBER Macroeconomics Annual, ed. Ben Bernanke and Julio Rotemberg. Cambridge, MA: MIT Press.

Hoshi, Takeo, and Anil Kashyap. 2001. Corporate Financing and Governance in Japan. Cambridge, MA: MIT Press.

Issing, Otmar. 2003. Monetary and Financial Stability: Is There a Tradeoff? In Monetary Stability, Financial Stability, and the Business Cycle: Five Views. BIS Papers 18. Basel: Bank for International Settlements.

Jinushi, Toshiki, Yoshihiro Kuroki, and Ryuzo Miyao. 2000. Monetary Policy in Japan Since the Late 1980s-Delayed Policy Actions and Some Explanations. In Japan's Financial Crisis and Its Parallels to U.S. Experience, ed. Ryoichi Mikitani and Adam Posen. Washington: Institute for International Economics.

Kiyotaki, Noburo, and John Moore. 1997. Credit Cycles. Journal of Political Economy 105, no. 2: 211-48.

King, Mervyn. 2003. No Money, No Inflation-The Role of Money in the Economy. In Central Banking, Monetary Theory, and Practice: Essays in Honour of Charles Goodhart, Volume 1, ed. Paul Mizen. Edward Elgar.

Laubach, Thomas, and Adam Posen. 1997. Disciplined Discretion: Monetary Targeting in Germany and Switzerland. Princeton Essays in International Finance 206 (December).

Meyer, Laurence. 2001. Lessons of the Japanese Deflation. Center for Strategic and International Studies, Washington. Photocopy.

Mikitani, Ryoichi, and Adam Posen, eds. 2000. Japan's Financial Crisis and Its Parallels to U.S. Experience. Washington: Institute for International Economics.

Miller, Marcus, Paul Weller, and Lei Zhang. 2002. Moral Hazard and the U.S. Stock Market: Analyzing the Greenspan Put. Economic Journal 112. 
Mishkin, Frederic, and Eugene White. 2002. U.S. Stock Market Crashes and Their Aftermath: Implications for Monetary Policy. NBER Working Paper 8922 (June). Cambridge, MA: National Bureau of Economic Research.

Posen, Adam. 2003a. It Takes More Than a Bubble to Become Japan. In Asset Prices and Monetary Policy, ed. Anthony Richards. Reserve Bank of Australia.

Posen, Adam. 2003b. A Strategy to Prevent Future Crises: Safely Shrink the Banking Sector. In Financial Crises in Japan and Latin America, ed. Edgardo Demaestri and Pietro Masci. Inter-American Development Bank.

Posen, Adam. 2001. Macroeconomic Policy Options and Prospects for Japan. Paper presented at the conference on Where Does the Japanese Economy Go from Here? Columbia Business School Center on Japanese Economy and Business, November 2, New York.

Posen, Adam. 1998. Restoring Japan's Economic Growth. Washington: Institute for International Economics.

Rich, Georg. 2003. Swiss Monetary Policy Targeting, 1974-1996: The Role of Internal Policy Analysis. ECB Working Paper 236 (June). Frankfurt: European Central Bank.

Romer, Christina, and David Romer. 2000. Federal Reserve Information and the Behavior of Interest Rates. American Economic Review 90 (June): 429-57.

Roubini, Nouriel. 2006. Why Central Banks Should Burst Bubbles. International Finance 9, no. 1 (forthcoming).

Schinasi, Garry. 2005a. Financial Architecture of the Eurozone at Five. In The Euro at Five: Ready for a Global Role, ed. Adam Posen. Washington: Institute for International Economics.

Schinasi, Garry. 2005b. Safeguarding Financial Stability: Theory and Practice. Washington: International Monetary Fund.

Shiller, Robert. 2005. Irrational Exuberance, 2d ed. Princeton, NJ: Princeton University Press. 